\title{
VARIATION WITH STREAM ORDER IN SPECIES \\ COMPOSITION, DIVERSITY, BIOMASS, AND \\ CHLOROPHYLL OF PERIPHYTON IN \\ OTTER CREEK, OKLAHOMA
}

\author{
By \\ JAMES RANDALL SEYFER \\ Bachelor of Science \\ Kearney State College \\ Kearney, Nebraska \\ 1974
}
Submitted to the Faculty of the Graduate College of the Oklahoma State University in partial fulfillment of the requirements for the Degree of MASTER OF SCIENCE July, 1976




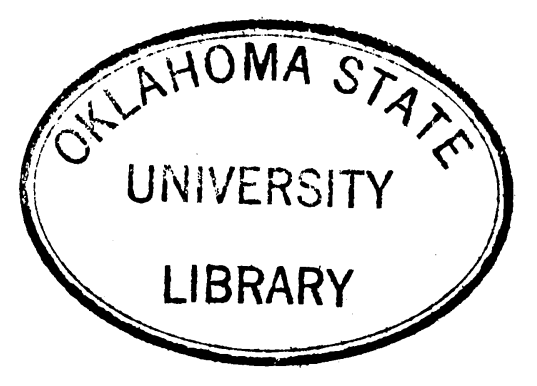

VARIATION WITH STREAM ORDER IN SPECIES

COMPOSITION, DIVERSITY, BIOMASS, AND

CHLOROPHYLL OF PERIPHYTON IN

OTTER CREEK, OKLAHOMA

Thesis Approved:

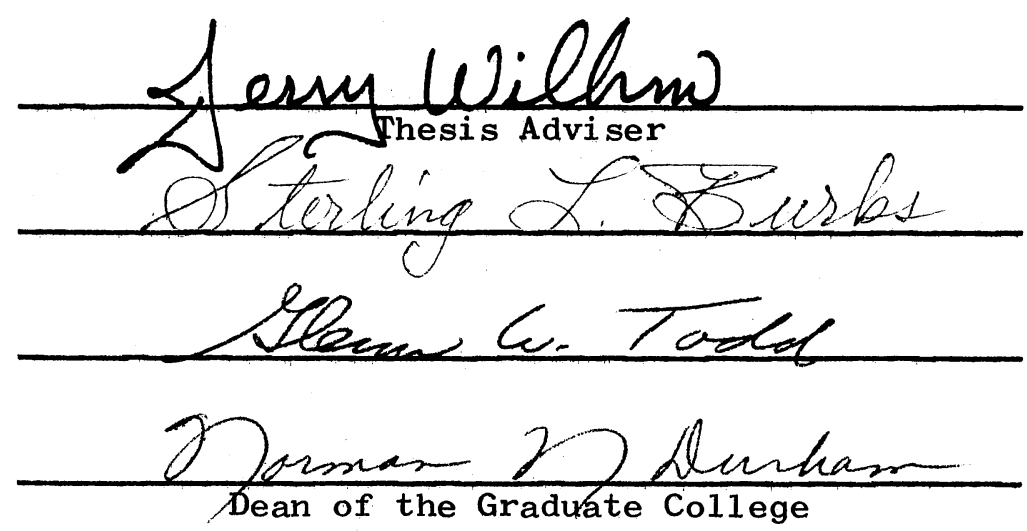

953420 


\section{ACKNOWLEDGMENTS}

Dr. Jerry Wilhm served as major adviser and provided considerable help and encouragement. My thanks also go to Drs. Sterling Burks and Glenn Todd for serving on my advisory committee. Dr. Donald Holbert provided much needed and appreciated assistance with the statistical analysis. Assistance with field collections from Steve Monn, Mike O'Hara, and David Parrish was greatly appreciated. Assistance with identification of algae came from Dr. J. M. Cooper and Mr. Gordon Smith. Thanks are also due to Drs. Ole Kolstad, Harold Nagel, and Marvin Williams who provided encouragement and gave direction for my undergraduate study. Thanks also to my parents, Mr. and Mrs. R. W. Seyfer, for assistance and encouragement thoughout my academic career. I also appreciate the loving encouragement and assistance of my wife, Ruth. 


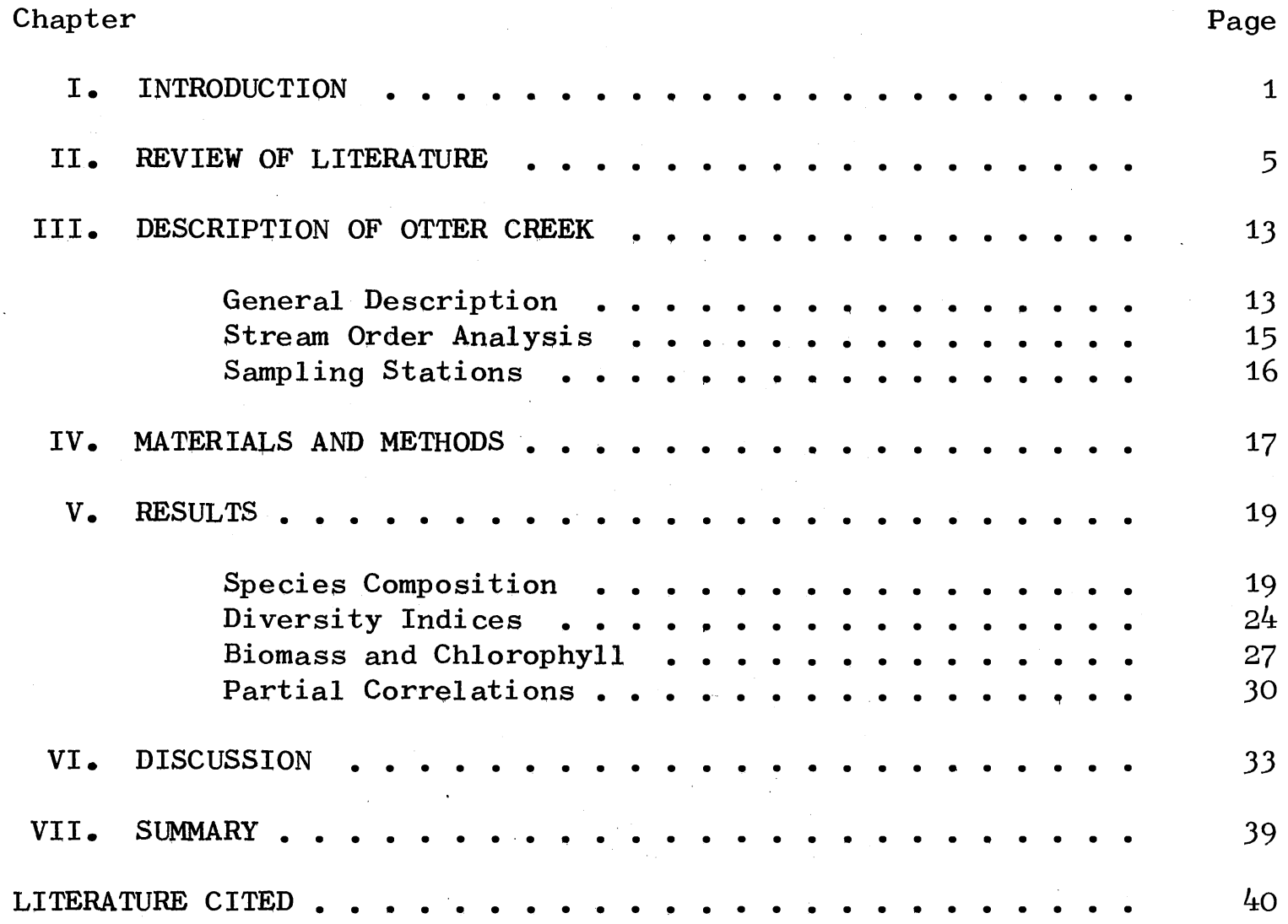




\section{LIST OF TABLES}

Table

Page

I. Stream Order Analysis of Otter Creek Drainage Basin . • 15

II. Periphyton Taxa Collected in Otter Creek, 1975 . . . . . 20

III. Four Most Abundant Species Per Order and Percent Composition of Each ...............

IV. Mean Number of Species ( $S$ ), Number of Diatom Species $\left(S_{d}\right)$, Species Diversity $(\bar{d})$, Equitability $(\mathrm{J})$, and Variety $(\mathrm{d})$ of Periphyton Assemblages by Stream Order and Period for Otter Creek, 1975 ..............

V. Chlorophyll a (CHL_A), Pheophytin a (PHEO_A), Dry Weight (DW), Ash-Free Weight (AFW), and Percent Ash (PA) of Periphyton Assemblages by Stream Order and Period for Otter Creek, 1975 . . . . . . . . . . .

VI. Partial Correlations of Variables Adjusted for All Effects and Interactions of the Design .........

\section{LIST OF FIGURES}

Figure

Page

1. Otter Creek Drainage Basin and Collecting Stations . . . 14 


\section{CHAPTER I}

\section{INTRODUCTION}

Stream communities have been classified by various methods such as productivity (Odum 1956), species composition (Forbes 1913), faunal and floral zonation (Forbes and Richardson 1913), community diversity (Margalef 1951), and various physicochemical parameters (Hynes 1960). Gravelius (1914) suggested classifying streams according to the degree of branching, with the largest stream in a system being first order. A scheme based on the inverse of Gravelius' system was devised by Horton (1945) and modified by Strahler $(1954,1957)$. In Horton's system of stream order analysis, first order streams are the smallest unbranched tributaries in a basin. Two first order streams join to form a second order, and successive orders are formed by the joining of two streams of the preceding order. Order designation does not change with the entrance of an adventitious stream of a lower order into a higher order stream.

Horton's system has several inherent physical characteristics. An inverse geometric relationship exists between stream order and total stream length and between stream order and average gradient (Horton . 1945). Stream order also has a direct geometric relationship with mean length of streams and drainage area (Horton 1945). Strahler (1957) showed a direct relationship between stream order and watershed dimensions, channel size, and stream discharge. Physicochemical fluctuations 
are more marked in upper stream reaches than in higher orders (Harrel and Dorris 1968, Whiteside and McNatt 1972). Turbidity and water temperature decrease with increasing stream order, while alkalinity and conductivity increase (Harrel and Dorris 1968). Thus, certain abiotic conditions can be predicted from a knowledge of stream order.

Streams of a specific order have certain predictable biological, as well as physicochemical characteristics. Species diversity, redundancy, and heterogeneity of benthic macroinvertebrates decrease as stream order increases. In third to fifth order streams, annual numbers of species and total community species diversity increased (Harrel and Dorris 1968), A decrease in the sixth order was attributed to flooding and heavy siltation. Species diversity of fish has been shown to increase with increasing stream order (Kuehne 1962, Harrel, et al. 1967, Whiteside and McNatt 1972, Lotrich 1973). Increases in fish diversity have been attributed to greater abundance and variety of food (Lotrich 1973), increases in habitat, and decreases in environmental harshness in higher stream orders (Harrel, et al. 1967). Thus, higher stream orders support a more diverse assemblage of fish and benthic macroinvertebrates.

Although the biological effects of pollution have been studied in many streams, the effects of succession were not considered. The subjectiveness of conventional methods of stream classification makes it difficult to locate the same successional stages in two different streams. Harrel and Dorris (1968) stated that because stream order analysis allows quantitative comparisons of streams in the same order, it may be possible to separate the effects of pollution from those of natural succession.

The concept of stream order has been applied mainly to fish and 
benthic macroinvertebrates. Most attempts to quantify natural variation of periphyton assemblages merely list the algae and their associations (Budde 1932, Symoens 1951, Margalef 1960). A need exists to separate the effects of pollution and succession on periphyton, since these organisms are commonly used in pollution studies. In the present study, an attempt was made to use stream order to delineate the natural succession of periphyton assemblages.

A number of different indices have been proposed to evaluate biotic assemblages in streams. The following $\bar{d}$ expression is a reasonable meașurement of species diversity:

$$
\bar{d}=-\sum\left(\frac{n_{i}}{n}\right) \log _{2}\left(\frac{n_{i}}{n}\right) \quad(\text { Patten 1962) }
$$

where $n_{i}$ is the sample estimate of the number of individuals in the $i$ 'th species and $\mathrm{n}$ is the total number of individuals sampled. Weber (1973) suggested that $\bar{d}$ lacks the sensitivity to show differences in slight to moderate levels of degradation. An equitability expression (J) such as the following may show these changes:

$$
J=\bar{d} / \log _{2} S \quad(\text { Pielou 1966), }
$$

with $S$ being the number of species per sample. This equation is relatively indifferent to the number of species in a sample (Sheldon 1969). Equations related to variety (d) have also been proposed such as:

$$
\mathrm{d}=\frac{\mathrm{S}-1}{\ln \mathrm{n}} \quad \text { (Margalef 1958). }
$$

In the present study $\bar{d}, J$, and $d$ in different stream orders were examined.

Two commonly measured parameters of the periphyton assemblage are 
ash-free weight and chlorophyll a.. Grzenda and Brehmer (1960) measured both parameters in Red Cedar River, Michigan. Ash-free weight is a measure of the organic matter in the periphyton and averages about $20 \%$ of the dry weight (Sladecek and Sladeckova 1964). Chlorophyll a has been used to approximate the photosynthetic rate in streams (McConnell and Sigler 1959). Pheophytin a , a degradation product of chlorophyll a, is used as a physiological condition indicator that varies with different environmental conditions (Yentsch and Menzel 1963). The usefulness of these parameters in evaluating periphyton in different stream orders was evaluated in the present study.

The following null hypotheses were tested;

1. $\mathrm{H}_{\mathrm{O}}$ : There is no significant difference in species composition of periphyton in different stream orders.

2. $H_{0}$ : There is no significant difference in species diversity, equitability, and variety of periphyton in different stream orders.

3. $H_{0}$ : There is no significant difference in chlorophyll a of periphyton per sample in different stream orders.

4. $\mathrm{H}_{\mathrm{o}}$ : There is no significant difference in ash-free weight of periphyton in different stream orders. 
CHAPTER II

\section{LITERATURE · REVIEW}

Periphyton is commonly defined as the assemblage of organisms growing upon free surfaces of submerged objects in water. This slippery brown or green layer is usually found adhering to the surfaces of water plants, wood, stones, or certain other objects immersed in water and may develop from a few gelatinous plants into a woolly, felted coat that may be slippery or crusty with contained marl or sand (Young 1945). Cooke (1956) and Sladeckova (1962) discussed periphyton terminology. Several reviews of methodology are also available (Lund and Talling 1957, Sladeckova 1962, Sladecek and Sladeckova 1964). Current recommended methods for periphyton collection are detailed by Weber (1973).

Early studies of stream periphyton were qualitative since removal of periphyton for quantitative analysis from rough and uneven natural substrate is difficult. Thus, many authors resorted to using submerged artificial substrates. The first documented use of artificial substrate was in 1915 (Naumann, cf. Cooke 1956); however, the method was not popularized until several years 1 ater by Butcher in a series of papers (1932, 1932a, 1940, 1946, 1947). Many different types of artificial substrates have been used such as concrete cylinders (McConnell and Sigler 1959), wooden platforms (Weigert and Fraleigh 1972), and styrofoam floats (Hohn and Hellerman 1963). The two most common types of substrates used today are glass slides (Butcher 1932) and plexiglass 
plates (Grzenda and Brehmer 1960). Artificial substrates are typically either attached to a horizontal bar on a,stake driven into the stream bed (Butcher 1932) or attached on floats called diatometers where the substrate is suspended just below the surface of the water (Patrick, et al. 1954). Since artificial substrates are of known area, quantitative samples can be taken.

The pattern of succession on artificial substrates prior to algal attachment has been well studied. It is probable that sorption of dissolved organic matter on to the artificial substrate precedes bacterial colonization (Hutchinson 1975). After about 1 day's exposure there is an appreciable population of bacteria, then as other organisms appear bacteria tend to decline in numbers (Karsinkin 1934, cf. Hutchinson 1975). The first eucaryotic colonists are flagellates and sessile protozoa, followed by rotifers, motile ciliates, and diatoms (Ivlev 1933). The diatoms begin to develop after about 2 days (Patrick 1967)。

Douglas (1958) questioned whether the same species occur in the same quantity and with the same spatial relationships on artificial substrate as on natural substrate. Between 75 to $85 \%$ of the diatom taxa collected from natural substrates are collected on glass slides (Patrick, et al. 1954). It has also been suggested that at low water temperatures, styrofoam substrates prove more representative than smooth artificial substrates. However, Dillard $(1969,1971)$ determined that the glass slide method was superior because of its simplicity and reproducibility and that low temperatures did not significantly affect the results of the glass slides. Castenholtz (1961) evaluated periphyton attachment and production on both smooth and frosted glass and plexiglass. In 
addition, he looked at black-backed, white-backed, and clear plates and found no significant differences. He also suggested that in lakes horizontal slides come closer to duplicating natural epilithic assemblages than vertical slides. However, artificial substrate in streams are usually placed in a vertical position, parallel to the current, to avoid siltation (Patrick, et al.1954).

There are several factors that influence attachment of periphyton to artificial substrates. The kinds of organisms present, the number of available propagules, and the succession before algal attachment seem to be the most important biological factors. Several investigators have shown that fast currents retard the initial attachment of algae to glass slides, but after 3 to 4 weeks the problem was alleviated and the faster cyrrents produced the greater biomass (McIntire 1966, Reisen and Spencer 1970). Detergents may also interfere with the adhesion of periphyton to a substrate (Cooper and Wilhm 1975).

The artificial substrate method has been used to produce estimates of production. Newcombe $(1949,1950)$ was among the first to use artificial substrate to estimate lake periphyton production. He realized that the ash-free dry weight of periphyton was an estimate of net primary production. Sladecek and Sladeckova (1964) reviewed the different methods used for the analysis of production on artificial substrate. The instantaneous biomass accumulation method (Kevern, et al. - 1966) provided a refinement of production estimates in that only the acceleration phase of periphyton growth is considered. Thus, estimates from the instantaneous biomass accumulation method are higher. Cooper and Wilhm (1975) found that production, estimated by this method ranged from 0.53 to $3.73 \mathrm{~g} \mathrm{~m}^{-2} \mathrm{day}^{-1}$ in Skeleton Creek, Oklahoma. In the 
Jordan River, Michigan, production values ranged from $0.01 \mathrm{~g} \mathrm{~m}^{-2}$ day $^{-1}$ in a non-polluted area to $0.10 \mathrm{~g} \mathrm{~m}^{-2} \mathrm{day}^{-1}$ in an area influenced by fish hatchery effluent (Ball et al. 1973). In addition to perturbation studies the method holds promise as a bioassay technique (S。L。Burks, personal communication).

Because chlorophyll a roughly approximates the rate of photosynthesis, it has been used as a measure of productivity (Ryther 1956, Waters 1961, Yount 1956). Several studies have shown a strong positive correlation between chlorophyll content and biomass (McConnell and Sigler 1959, Grzenda and Brehmer 1960). This relationship has enabled biomass to be used as a predictor of chlorophyll a (Fraleigh and Weigert 1975). Yount (1956) used the rate of chlorophyll accumulation on artificial substrate as a measure of productivity. McConnell and Sigler (1959) used chlorophyll on concrete cylinders to measure productivity. They demonstrate the superiority of this method in shallow streams over Odum's (1956) diurnal oxygen curve technique. Chlorophyll a has been substituted for ash-free dry weight in the instantaneous biomass accumulation method, in order to eliminate the biomass of consumers (Wilhm and Long 1969). A few studies have used this method in laboratory situations (Wilhm and Long 1969, Kehde and Wilhm 1972), but not until recently has it been applied to a natural situation (Tilley and Haushild 1975a, 1975b). However, the variability of chlorophyll a is a drawback. This variation is attributed to a combination of organic detritus accumulation and death of individuals in the assemblage (Grzenda and Grehmer 1960).

Succession is an incessant process which results in temporal changes in both the environment and community (Margalef 1960). It is 
also an orderly, directional process which is predictable and culminates in a stabilized ecosystem (E. P. Odum 1969, 1971). The strategy of succession is to obtain homeostasis with the physical environment. The relegation of increasingly more energy to maintenance during succession is one means by which a system reaches homeostasis (H. T. Odum and Pinkerton 1955). Succession starts when there are enough nutrients to support a heavy growth and continues until those nutrients are used up (Margalef 1958). This depletion of nutrients along with the shift from inorganic to organic nutrients causes the above mentioned shift in energy flows (E. P. Odum 1969).

The best studied type of succession is temporal. In the first stage of succession in marine phytoplankton, small-celled organisms have a high surface/volume ratio, simple life histories, and rapid rates of increase dominate. This stage is then followed by increasingly larger organisms of the same species or of different species with more complex life cycles, smaller surface/volume ratios, and lower rates of potential increase (Margalef 1958). The shift in nutrients from inorganic to organic may be the cause of size changes during succession. The selective advantage given to small sized organisms in early succession is that they have a greater surface/volume ratio and are therefore more efficient at taking up the nutrients (Frank 1968, E. P. Odum 1969). As succession proceeds the inorganic nutrients become tied up in biomass thus large organisms with large storage capacities for exploiting new situations are selected (E. P. Odum 1969).

Longitudinal succession is the only general and unifying biological characteristic of streams (Margalef 1960). Eddy (1925) found diatoms (mostly Synedra), Euglena and Phacus were dominants at the source of a 
glacial stream. At a descent of $6 \mathrm{~m}$ filamentous algae first appeared. Attempts have been made to delineate successional stages in a stream by identification of algal communities (Margalef 1960). Johnson et al. (1975) studied diatom populations in rhithron and potamon regions of Oak Creek, Arizona. Rhithron regions have lower temperatures, higher dissolved oxygen, and faster currents than the downstream potamon region. They point out that Meridion circulare, Nitzschia palea, Gomphonema parvulum, and Fragilaria vaucheriae are representative of the rhithron, and that Epithemia sorex, E. turgida, and Amphipleura pellucida are representative of the potamon. In addition, 34 species were found at rhithron stations and only 20 at potamon stations. The number of species in the Metolius River, Oregon, tended to increase downstream and then level off, with no filamentous algae at the headwaters (Sherman and Phinney 1971). In a lake-fed mountain stream in the Rila Mountains, Bulgaria, the number of species tended to decrease with decreasing altitudes (Kawecka 1974). However, blue-green algae dominated along with diatoms at the headwaters. Gomphonema olivaceum, Diatoma vulgare, Hannaea arcus, Hydrurus foetidus, and Eunotia pectinalis have all been recognized as pioneer organisms in streams (Blum 1954, Margalef 1960, Dillard 1969).

Seasonal variation of periphyton in streams is well studied. Butcher (1932) found two annual phases in a large fast-flowing English river, the diatom phase in spring and the Cocconeis-Ulvella-Chamesiphon phase in the winter. Butcher (1940) found no seasonal variation in a slow-flowing English canal. In an unpolluted stretch of the Saline River, Cladophora glomerata was the dominant in spring and Diatoma vulgare and Gomphonema olivaceum were dominants in winter. In a 
polluted stretch Nitzschia palea and Stigeoclonium tenue were the summer dominants, with Tetraspora sp., Navicula atomus, and Spirogyra sp. as dominants at other seasons (Blum 1957). Douglas (1958) discusses periodicity of Achnanthes spp. In the West Gallatin River numbers of algae varied somewhat proportionally to water temperature, except during periods of high discharge when numbers were lowest (Gumtow 1955). Hynes (1970) points out that temperature and light influence seasonal changes in flora, but are difficult to disentangle from one another.

An increase in the number of niches occurs during succession (Margalef 1958). Odum (1969) states that the behavior of species diversity may depend on whether the increase in potential niches resulting from increased biomass, pattern diversity, and other biological parameters exceeds the countereffects of increasing size and competition. Some authors have found that species diversity steadily increases during succession (Margalef 1968), while others have found that it increases during early succession and then decreases in the later stages (Whitaker 1965). With an increase in the number of niches, an increased variety of organisms can be developed and the dominance of any one species or any small group of species is reduced (Odum 1969).

A few reviews of $\bar{d}$-values are available for benthic macroinvertebrates (Wilhm and Dorris 1968, Wilhm 1970), phytoplankton (Staub, et al. 1970), and fish (Wilhm 1976). Diversity values for benthic macroinvertebrates of less than one have been found in areas of heavy pollution, with values exceeding three in clean water (Wilhm and Dorris 1968). Staub, et al. reported $\bar{d}$ values of less than one in areas of severe pollution, from one to two areas of moderate pollution, from two to three in areas of 1 ight pollution, and values from three to four in 
slightly polluted areas.

Even though wilhm (1976) does not evaluate $\overline{\mathrm{d}}$ on a pollutional basis, it can be seen that values are lower for fish than other organisms. Patrick (1968) found that diversity values were similar in similar ecological conditions. In a relatively eutrophic lake $\overline{\mathrm{d}}$ values of 2.03 to 3.17 were found (Brown 1973). Ball et al. (1973) looked at periphyton species diversity and equitability in three Michigan streams varying from undisturbed to heavily polluted. They found high diversity indices were associated with low water quality and vice versa, and that equitability showed no trends related to disturbances. However, others have shown the species diversity of periphyton improves with improving water quality (Bahls 1973, Cooper and Wilhm 1975). 
CHAPTER III

\title{
DESCRIPTION OF OTTER CREEK
}

\author{
General Description
}

Otter Creek, an intermittent, sixth-order stream in northcentral Oklahoma (Figure 1), flows southward from near Covington into Skeleton Creek, a tributary of the Cimarron River. It is $41.8 \mathrm{~km}$ long with an average gradient of $1.8 \mathrm{~m} / \mathrm{km}$. The basin has an irregular perimeter of $106.2 \mathrm{~km}$ and an area of $302.1 \mathrm{~km}^{2}$. Underlying the entire area is the "Permian red beds" named for their color and geologic time period when formed (Fitzpatrick, et al. 1939). The Hennessey formation, made up primarily of shales with some gypsum and lenticular sandstone, is exposed in the upper parts of the basin. In the rest of the basin, the Garber formation is exposed, which consists of alternating sandstone and shales with interstratified beds of limestone and gypsum (USGS 1945). Although Garber sandstone is one of the most important aquifers in the state, the water is hard and high in sulfates and chlorides (USGS 1945 ). The soils are of the Renfrow-Zaneis-Vernon association and are composed of sandy or clayey silts and loams (Gray and Galloway 1959). The basin is part of the mixed-grass prairie association with trees being mainly restricted to the valleys. Much of the land in the area is either pasture or cultivated.

The climate is long-summer continental with an average precipitation of $81 \mathrm{~cm}$ per year and an average temperature of $16 \mathrm{C}$. Wide 


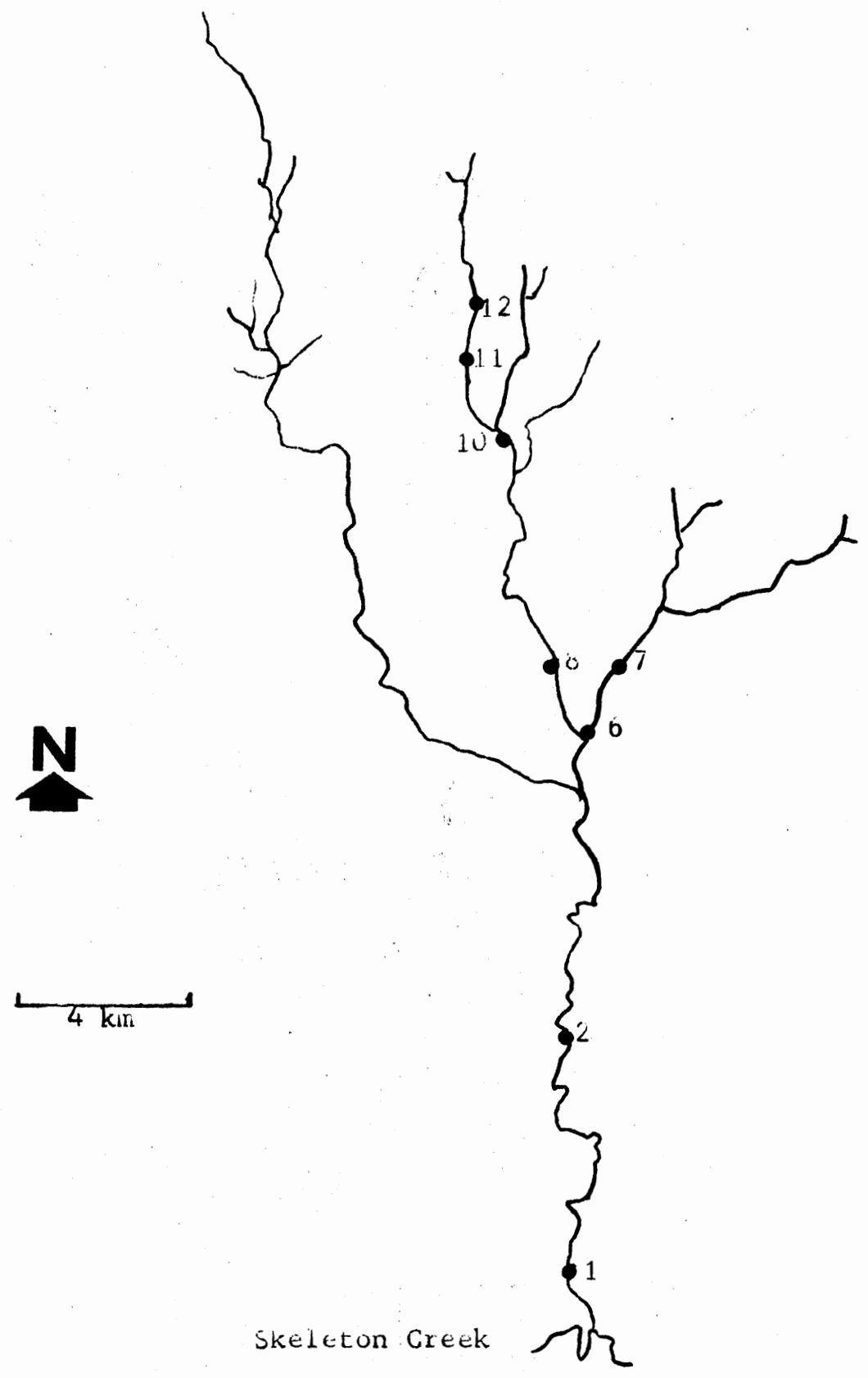

Figure 1. Otter Creek Drainage Basin and Collecting Stations. Stations are as follows: 11 and 12 are 3 rd order, 8 and 10 are 4 th order, 6 and 7 are 5 th order, 1 and 2 are 6 th order. 
fluctuations of annual precipitation and daily temperatures occur with severe droughts being common (Fitzpatrick, et al. 1939, Galloway 1960).

\section{Stream Order Analysis}

Table I shows a stream order analysis of Otter Creek. The bifurcation ratio, the ratio between the number of streams in a certain order and the number in the next higher order, is 3.97. This is high and indicates a well-dissected basin (Horton 1945). The stream-length ratio, the ratio of the average length of streams in a certain order to the average 1 ength in the next lower order, is 2.08 . The ratio is low indicating a well-drained basin. A low drainage density (total stream length/area) of 2.04 and a high stream frequency (number of streams/area) of 3.25 verify that it is a well-drained basin.

TABLE I

STREAM ORDER ANALYSIS OF OTTER CREEK DRAINAGE BASIN (Harrel 1966)

\begin{tabular}{ccccc}
\hline Order & Number of Streams & $\begin{array}{c}\text { Total Length } \\
(\mathrm{km})\end{array}$ & $\begin{array}{c}\text { Average Length } \\
(\mathrm{km})\end{array}$ & $\begin{array}{c}\text { Mean Drainage Area } \\
\left(\mathrm{km}^{2}\right)\end{array}$ \\
\hline 1 & 744 & 300.6 & 0.40 & \\
2 & 189 & 163.8 & 0.87 & 5.3 \\
3 & 39 & 83.4 & 2.14 & 27.9 \\
4 & 7 & 35.2 & 5.04 & 126.2 \\
5 & 2 & 19.5 & 9.75 & 302.1 \\
6 & 1 & 14.6 & 14.60 & \\
\hline
\end{tabular}




\section{Sampling Stations}

Eight stations were selected from the stations established by Harrel (1966). Stations 1 and 2 are in the sixth order, 6 and 7 in the fifth order, 8 and 10 are in the fourth order, and 11 and 12 are in the third order. 


\section{CHAPTER IV}

\section{MATERIALS AND METHODS}

Periphyton samples were taken from two stations each at third, fourth, fifth, and sixth order streams. At each station four diatometers were exposed for 3 wk periods in winter, spring, and summer. Each diatometer consisted of six $8 \times 11 \mathrm{~cm}$ plexiglass plates supported by two parallel threaded rods, $30.5 \mathrm{~cm}$ in length. The rods were attached on each end to two $20 \times 2.5 \times 5.0 \mathrm{~cm}$ redwood slats which provide flotation. The plates were separated on the rods by $2.5 \mathrm{~cm}$ lengths of polyethylene tubing. A $4 \mathrm{~cm}$ length of tubing separated the end plates from the slats. The samplers were set in the stream so that the plexiglas plates were parallel to the current. Two samples each were collected at each station for determining species identification, ashfree weight, and chlorophyll a. Each sample was taken by scraping two plates randomly selected from two diatometers into collection jars containing FAA, ethanol, and distilled water, respectively. Chlorophyll a and ash-free weight were analyzed immediately.

Ash-free weight was determined by washing the periphyton into a tared crucible and drying in an oven at $105 \mathrm{C}$ for $24 \mathrm{~h}$ (Weber 1973). The material was then ashed at $500 \mathrm{C}$ for $1 \mathrm{~h}$, the ash rewetted, and redried at $105 \mathrm{C}$ for $4 \mathrm{~h}$. Before dry and ash weights were determined the crucibles were cooled in a desiccator.

Chlorophyll a and pheophytin a were extracted in $20 \mathrm{ml}$ of $90 \%$ 
aqueous acetone (Weber 1973). The extraction was done at $4 \mathrm{C}$ for $24 \mathrm{~h}$ in the dark. A Beckman DBG spectrophotometer was used to determine the concentrations of chlorophyll a and pheophytin $\underline{a}$ by the equations of Lorenzen (1967).

Periphyton identification samples were analyzed on cleared Millipore membrane filters with pore size $0.45 \mu$. Permanent mounts were made with Arochlor 5442. From each sample two aliquots were filtered. From each filter 200 individuals were counted. The numbers from each filter were pooled and used for calculations.

The following split-plot in time analysis of variance was used (Steel and Torrie 1960):

Source

Total

Orders

Stations

Station $\mathbf{x}$ Order

Error(a)

Periods

Period $\mathbf{x}$ Order

Period $\mathbf{x}$ Station

Period $\mathrm{x}$ Station $\mathbf{x}$ Order

Error (b) d. $f$.

35

3

1

3

8

2

6

2

4

6

A protected Least Significant Difference was used where significant differences occurred. 


\section{CHAPTER V}

\section{RESULTS}

Several samples were not collected because of vandalism and bad weather. During winter only one sample per station was collected and inclement weather prevented the resetting of samplers. In spring stations $1,2,7$, and 8 were lost because of heavy rains and were reestablished. Heavy rains again destroyed the samplers at stations 1 and 8 and they were not reset. Only in summer were all samplers collected. The stations in order 3 through 5 did not dry up as was found by Harrel (1966).

\section{Species Composition}

Eighty-five taxa of periphyton were identified from Otter Creek (Table II), 78 belonging to the Bacillariophyta. There were 52, 56, and 69 taxa identified in winter, spring, and summer, respectively. During winter Gomphonema olivaceum comprised $24 \%$ of the total taxa collected and Stigeoclonium tenue made up over $14 \%$. Navicula tripunctata and Nitzschia palea were the most abundant taxa present in the whole study as well as in spring, making up $20 \%$ and $11 \%$, respectively, in spring. In summer, Diploneis smithii constituted $17 \%$ and $\underline{N}$. palea $11 \%$ of the number of taxa.

Using the method of Williams and Scott (1962) the species composition in Otter Creek was compared among orders (Table III). During the 
TABLE II

PERIPHYTON TAXA COLLECTED

IN OTTER CREEK, 1975*

BACILLARIOPHYTA

Centrales

Coscinodiscus sp.

Cyclotella atomus Hust.

Cyclotella stelligera C1. \& Grun.

Cyclotella meneghiniana Kutz.

Melosira italica (Ehr.) Kutz.

Melosira varians Ag.

Stephanodiscus astrea (Ehr.) Grun.

Stephanodiscus hantzschii Grun.

Pennales

Achnanthes exigua var. heterovalva Krasske

Achnanthes haukiana Grun.

Achnanthes lanceolata (Breb.) Grun.

Achnanthes minutissima Kutz.

Amphipleura pellucida Kutz.

Amphora oval is (Kutz.) Kutz.

Bacillaria paradoxa Gmel.

Caloneis bacillum (Grun.) $\mathrm{Cl}$.

Caloneis lewisii Patr.

Caloneis ventricosa (Ehr.) Meist.

Cocconeis placentula Ehr.

Cymatopleura elliptica (Breb.) W. Sm.

Cymbella minuta Hilse ex Rabh.

Diatoma vulgare Bory

Diploneis smithii (Breb. ex W. Sm.) Cl.

Entomoneis paludosa (W. Sm.) Reim.

Eunotia curvata (Kutz.) Lagerst.

Frustulia vulgaris (Thwaites) DeT.

Gomphonema olivaceum (Lyngb.) Kutz.

Gomphonema parvulum Kutz.

Gomphonema subclavatum (Grun.) Grun.

Gomphonema truncatum Ehr.

Gyrosigma spencerii (Quek.) Griff. \& Henfr. Meridion circulare (Grev.) Ag.

Navicula angusta Grun.

Navicula capitata Ehr.

Navicula cryptocephala Kutz.

Navicula cuspidata (Kutz.) Kutz.

Navicula laevissima Kutz.

Navicula minima Grun.

Navicula mutica Kutz.

Navicula pelliculosa (Breb. ex Kutz.) Hilse 
TABLE II (Continued)

Navicula pupula Kutz.

Navicula pygmaea Kutz.

Navicula salinarum Grun.

Navicula tenera Hust.

Navicula tripunctata (0. Mul1.) Bory

Navicula sp. 1

Navicula sp. 2

Neidium affine (Ehr.) Pfitz.

Nitzschia acicularis W. Sm.

Nitzschia amphibia Grun.

Nitzschia angustata (W. Sm.) Grun.

Nitzschia apiculata (Greg.) Grun.

Nitzschia denticula Grun.

Nitzschia filiformis (W. Sm.) Hust.

Nitzschia hungarica Grun.

Nitzschia linearis W. Sm.

Nitzschia obtusa var. scalpelliformis Grun.

Nitzschia palea (Kutz.) W. Sm.

Nitzschia parvula Lewis

Nitzschia sigma (Kutz.) W. Sm.

Nitzschia sigmoidea (Ehr.) W. Sm.

Nitzschia tryblionella Hantz.

Nitzschia sp. 1

Nitzschia sp. 2

Pinnularia braunii (Grun.) $\mathrm{Cl}$.

Pleurosigma delicatulum W. Sm.

Rhoicosphenia curvata (Kutz.) Grun. ex Rabh. Rhopalodia gibba (Ehr.) O. Mull.

Rhopalodia gibberula (Ehr.) O. Mull.

Surirella angustata Kutz.

Surirella brightwellii W. Sm.

Surirella ovata Kutz.

Surirella ovalis Breb.

Surirella robusta var. splendida (Ehr.) V。H.

Surirella sp.

Synedra fasciculata (Ag.) Kutz.

Synedra rumpens Kutz.

Synedra ulna (Nitz.) Ehr.

CHLOROPHYTA

Cosmarium sp.

Oedogonium sp.

Spirogyra sp.

Stigeoclonium tenue Huber

EUGLENOPHYTA

Euglena $\mathrm{sp.}$ 
TABLE II (Continued)

CYANOPHYTA

Oscillatoria sp.

Unknown

Unidentifiable filament

Nomenclature follows Hustedt (1930), Prescott (1962), and Patrick and Reimer (1966, 1975). 
TABLE III

FOUR MOST ABUNDANT SPECIES PER ORDER AND PERCENT COMPOSITION OF EACH

\begin{tabular}{|c|c|c|c|c|c|c|c|c|}
\hline \multirow{2}{*}{ PERIOD } & \multicolumn{7}{|c|}{ ORDER } & \\
\hline & \multicolumn{2}{|l|}{3} & \multicolumn{2}{|l|}{4} & \multicolumn{2}{|l|}{5} & \multicolumn{2}{|l|}{6} \\
\hline \multirow[t]{5}{*}{ Winter } & Stigeoclonium tenue & 33 & Gomphonema olivaceum & 30 & Gomphonema olivaceum & 36 & Meridion circulare & 16 \\
\hline & Gomphonema olivaceum & 14 & Stigeoclonium tenue & 25 & Navicula cryptocephala & 12 & Gomphonema ol ivaceum & 15 \\
\hline & Navicula cryptocephala & 13 & Cymbella minuta & 8 & Cymbella minuta & 9 & Synedra ulna & 15 \\
\hline & Navicula sp. 1 & 6 & Nitzschia amphibia & 7 & Navicula salinarum & 7 & Navicula $\mathrm{sp} .2$ & 12 \\
\hline & & 66 & & 70 & & 64 & & 58 \\
\hline \multirow[t]{5}{*}{ Spring } & Gomphonema parvulum & 22 & Navicula tripunctata & 56 & Achnanthes lanceolata & 30 & Cyclotella atomus & 32 \\
\hline & Nitzschia palea & 18 & Bacillaria paradoxa & 11 & Cocconeis placentula & 16 & Navicula tripunctata & 23 \\
\hline & Nitzschia tryblionella & 15 & Nitzschia amphibia & 8 & Achnanthes minutissima & 10 & Nitzschia palea & 12 \\
\hline & Nitzschia amphibia & 9 & Cyclotella meneghiniana & 5 & Nitzschia palea & 7 & Nitzschia amphibia & $\underline{4}$ \\
\hline & & 64 & & 80 & & 63 & & 71 \\
\hline \multirow[t]{5}{*}{ Summer } & Oscillatoria sp. & 25 & Diploneis smithii & 33 & Diploneis smithii & 20 & Nitzschia palea & 20 \\
\hline & Rhopalodia gibba & 13 & Nitzschia obtusa & 18 & Nitzschia palea & 13 & Navicula cryptocephala & 17 \\
\hline & Nitzschia obtusa & 9 & Bacillaria paradoxa & 8 & Gomphonema subclavatum & 8 & Navicula sp. 2 & 9 \\
\hline & Gomphonema parvulum & 9 & Nitzschia palea & 7 & Bacillaria paradoxa & 7 & Navicula tenera & 9 \\
\hline & & 56 & & 66 & & 48 & & 56 \\
\hline
\end{tabular}


winter G. olivaceum was abundant in all orders, while Meridion circulare was abundant only in the sixth order and $\underline{S}$. tenue only in the third and fourth orders. In spring $\underline{N}$. palea was abundant in all but the fourth order where $N$. tripunctata occurred in large numbers. Diploneis smithii was abundant in summer only in the fourth and fifth orders. Nitzschia palea numbers increased with order and Oscillatoria sp. and Rhopalodia gibba were present as dominants only in the third order.

When a split-plot in time Analysis of Variance (AOV) was conducted on the total number of species $(S)$, stream order was found to have a significant effect [Observed Significance Level (OSL) $<0.005$ ], but not period. However, when only the number of diatom species $\left(S_{d}\right)$ were analyzed both order and period were significant (OSL < 0.05). When orders were compared by Least Significant Difference (LSD) for both S and $S_{d}$ fourth and fifth order streams were not significantly different from each other (Table IV). When $S_{d}$ was tested over periods, winter and spring values were not significantly different.

\section{Diversity Indices}

Species diversity $(\bar{d})$ values ranged from 2.45 to 3.64 and averaged 3.19 (Table IV). Values generally increase with an increase in stream order. In spring a significant decrease occurred between third and fourth order streams. The minimum diversity, observed in spring in the fourth order stream, resulted from the diatom Navicula tripunctata which comprised $56 \%$ of the total number collected. The dominance of this species also resulted in the mean diversity of the spring value to be less than the mean of winter or summer. The AOV revealed that there were significant differences due to period and stream order. Third and 
TABLE IV

MEAN NUMBER OF SPECIES $(S)$, NUMBER OF DIATOM SPECIES $\left(S_{d}\right)$, SPECIES DIVERSITY ( $\left.\bar{d}\right)$, EQUITABILITY ( $\left.J\right)$, AND VARIETY (d) OF PERIPHYTON ASSEMBLAGES BY STREAM ORDER AND PERIOD FOR OTTER CREEK, 1975*

\begin{tabular}{|c|c|c|c|c|c|c|}
\hline \multirow{2}{*}{ Variable } & \multirow{2}{*}{$\begin{array}{l}\text { Sampling } \\
\text { Period }\end{array}$} & \multicolumn{4}{|c|}{ Order } & \multirow[b]{2}{*}{$\overline{\mathrm{x}}$} \\
\hline & & 3 & 4 & 5 & 6 & \\
\hline \multirow[t]{4}{*}{$\mathrm{S}$} & Winter & 24.0 & $26: 0$ & 23.5 & 23.5 & 24.8 \\
\hline & Spring & 22.5 & 20.0 & 26.0 & 27.5 & 24.1 \\
\hline & Summer & 21.5 & 29.5 & 29.3 & 31.5 & 27.9 \\
\hline & $\overline{\mathrm{x}}$ & 22.4 & 26.3 & 26.8 & 29.0 & 25.9 \\
\hline \multirow[t]{4}{*}{$\mathrm{S}_{\mathrm{d}}$} & Winter & 21.5 & 24.0 & 23.0 & 25.0 & 23.4 \\
\hline & Spring & 20.5 & 20.0 & 26.0 & $27 \cdot 5$ & 23.4 \\
\hline & Summer & 20.8 & 28.8 & 28.3 & 31.5 & $27 \cdot 3$ \\
\hline & $\overline{\mathrm{X}}$ & 20.8 & 25.4 & 26.3 & 28.9 & 25.1 \\
\hline \multirow[t]{4}{*}{$\overline{\mathrm{d}}$} & Winter & 3.13 & 3.23 & 3.16 & 3.50 & 3.26 \\
\hline & Spring & 3.00 & 2.45 & 3.13 & 3.25 & 2.99 \\
\hline & Summer & 2.95 & 3.08 & 3.56 & 3.64 & 3.31 \\
\hline & $\overline{\mathrm{X}}$ & 3.01 & 2.96 & 3.31 & 3.51 & 3.19 \\
\hline
\end{tabular}


TABLE IV (Continued)

\begin{tabular}{|c|c|c|c|c|c|c|}
\hline \multirow{2}{*}{ Variable } & \multirow{2}{*}{$\begin{array}{c}\text { Sampling } \\
\text { Period }\end{array}$} & \multicolumn{4}{|c|}{ Order } & \multirow[b]{2}{*}{$\overline{\mathrm{X}}$} \\
\hline & & 3 & 4 & 5 & 6 & \\
\hline \multirow[t]{4}{*}{$\mathrm{J}$} & Winter & 0.69 & 0.69 & 0.70 & 0.75 & 0.71 \\
\hline & Spring & 0.67 & 0.57 & 0.66 & 0.68 & 0.65 \\
\hline & Summer & 0.67 & 0.63 & 0.73 & 0.74 & 0.69 \\
\hline & $\overline{\mathrm{X}}$ & 0.67 & 0.63 & 0.70 & 0.73 & 0.68 \\
\hline \multirow[t]{4}{*}{ d } & Winter & 3.84 & 4.18 & 3.76 & 4.09 & 3.96 \\
\hline & Spring & 3.59 & 3.17 & 4.18 & 4.43 & 3.85 \\
\hline & Summer & 3.42 & 4.76 & 4.72 & 5.09 & 4.50 \\
\hline & $\overline{\mathbf{X}}$ & 3.57 & 4.22 & 4.31 & 4.67 & 4.16 \\
\hline
\end{tabular}

*Sample size: Winter--values are the average of two samples; Spring--average of two samples for fourth and sixth orders, four samples for third and fifth orders; Summer--average of four samples. 
fourth order values and winter and summer values were not significantly different.

Equitability $(\mathrm{J})$ varied from 0.57 to 0.75 with an average of 0.68 (Table IV). Winter values were fairly constant except for an increase of 0.05 between fifth and sixth order. The spring values in the fourth order were the lowest, probably for the same reasons as the low value of $\overline{\mathrm{d}}$. In summer, values were again the lowest in the fourth order resulting from the diatom Diploneis smithii which made up $33 \%$ of the total number collected. A difference existed due to stream order and the ISD disclosed that third order values were not significantly different from either fourth or fifth order values and that the fifth order was not different from the sixth order. No period differences existed $(\alpha=0.05)$

Variety (d) varied from 3.17 to 5.09 and averaged 4.16 (Table IV). Winter values of $\mathrm{d}$ showed no trends. In spring the fourth order values were the lowest reflecting the low number of species. Stream order had an effect, but fourth and fifth order values were not significantly different. No period differences were observed $(\alpha=0.05)$.

\section{Biomass and Chlorophyll}

The mean for chlorophyll a (CHL_A), was $5.64 \mathrm{mg} / \mathrm{m}^{2}$ and the range was from 0.21 to $15.34 \mathrm{mg} / \mathrm{m}^{2}$, both extremes occurring in soring (Table V). The low value in spring was probably caused by scour during high discharge. Values of chlorophyll a decreased with stream order. An AOV revealed only the third order was significantly different from the rest. A significant period $\mathbf{x}$ station interaction was disclosed, resulting from upstream values being significantly higher in spring. 
TABLE V

CHLOROPHYLL a (CHL_A), PHEOPHYTIN a (PHEO_A), DRY WT (DW), ASH-FREE WT (AFW), AND PERCENT ASH (PA) OF PERIPTHTON ASSEMBLAGES BY STREAM ORDER AND PERIOD FOR OTTER CREEK, 1975*

\begin{tabular}{|c|c|c|c|c|c|c|}
\hline \multirow{2}{*}{ Variable } & \multirow{2}{*}{$\begin{array}{l}\text { Sampling } \\
\text { Period }\end{array}$} & \multicolumn{4}{|c|}{ Order } & \multirow[b]{2}{*}{$\overline{\mathrm{X}}$} \\
\hline & & 3 & 4 & 5 & 6 & \\
\hline \multirow{4}{*}{ CHL_A } & Winter & $2.8 * *$ & 1.7 & 1.2 & 0.6 & 1.6 \\
\hline & Spring & 15.3 & -5.2 & 3.7 & 0.2 & 7.3 \\
\hline & Summer & 10.6 & 6.4 & 6.3 & 2.6 & 6.5 \\
\hline & $\overline{\mathrm{X}}$ & 10.9 & 4.9 & 4.2 & 1.5 & 5.6 \\
\hline \multirow[t]{4}{*}{ PHEO_A } & Winter & $0.8 * *$ & 0.3 & 0.4 & 0.2 & 0.4 \\
\hline & Spring & 2.6 & 0.0 & 0.1 & 0.1 & 0.9 \\
\hline & Summer & 0.9 & 0.1 & 0.3 & 0.3 & 0.4 \\
\hline & $\overline{\mathrm{X}}$ & 1.6 & 0.1 & 0.2 & 0.2 & 0.6 \\
\hline \multirow[t]{4}{*}{ DW } & Winter & $6.03 * * *$ & 1.99 & 2.01 & 2.22 & 3.06 \\
\hline & Spring & 25.66 & 30.79 & 5.48 & 1.79 & 15.81 \\
\hline & Summer & 25.34 & 7.65 & 9.68 & 9.83 & 13.12 \\
\hline & $\overline{\mathrm{X}}$ & 21.61 & 12.02 & 6.46 & 5.92 & 11.78 \\
\hline
\end{tabular}


TABLE V (Continued)

\begin{tabular}{|c|c|c|c|c|c|c|}
\hline \multirow{2}{*}{ Variable } & \multirow{2}{*}{$\begin{array}{c}\text { Sampling } \\
\text { Period }\end{array}$} & \multicolumn{4}{|c|}{ Order } & \multirow[b]{2}{*}{$\overline{\mathrm{x}}$} \\
\hline & & 3 & 4 & 5 & 6 & \\
\hline \multirow[t]{4}{*}{ AFW } & Winter & $0.86 * * *$ & 0.68 & 0.42 & 0.31 & 0.57 \\
\hline & Spring & $3 \cdot 36$ & 2.18 & 1.45 & 0.35 & 2.03 \\
\hline & Summer & $3 \cdot 51$ & 1.13 & 1.13 & 0.86 & 1.66 \\
\hline & $\overline{\mathrm{X}}$ & 2.92 & 1.28 & 1.12 & 0.59 & 1.54 \\
\hline \multirow[t]{4}{*}{$\mathbf{P A}$} & winter & 31.0 & 38.2 & 25.5 & 17.8 & 28.1 \\
\hline & Spring & 14.4 & 7.2 & 30.1 & 28.2 & 20.7 \\
\hline & Summer & 14.3 & 14.8 & 14.3 & 9.2 & 13.2 \\
\hline & $\overline{\mathrm{X}}$ & $17 \cdot 7$ & 18.7 & 22.8 & 16.1 & 19.0 \\
\hline
\end{tabular}

*Sample size: Winter--values are the average of two samples; Spring--average of two samples for fourth and sixth orders, four samples for third and fifth orders; Summer--average of four samples.

**values in $\mathrm{mg} / \mathrm{m}^{2}$

$* * *$ values in $\mathrm{g} / \mathrm{m}^{2}$ 
Pheophytin a (PHEO_A) ranged from 0.00 to $2.62 \mathrm{mg} / \mathrm{m}^{2}$ and averaged $0.58 \mathrm{mg} / \mathrm{m}^{2}$ (Table V). The extremes were found in the third and fourth orders of spring.

Values of dry weight (DW) varied from 1.79 to $30.79 \mathrm{~g} / \mathrm{m}^{2}$ and had a mean of $11.78 \mathrm{~g} / \mathrm{m}^{2}$ (Table V). In the fourth order stream in spring, values were maximum when a gritty discolored growth occurred on the plates. Significant order and period differences were found. Winter values were significantly lower than the other periods and only the third order was judged different from the other orders. Significant period $\mathrm{x}$ order, period $\mathrm{x}$ station, and period $\mathrm{x}$ order $\mathrm{x}$ station interactions were al so found.

Mean ash-free weight (AFW) was $1.54 \mathrm{~g} / \mathrm{m}^{2}$ and values ranged from 0.31 to $3.51 \mathrm{~g} / \mathrm{m}^{2}$ (Table V). Mean order values increased with decreased stream order. Significant order differences were found and only the fourth and fifth order values were not significantly different from each other. The upstream stations in all orders had a significantly higher value than downstream stations.

The percent ash (PA) ranged from 7.2 to $38.2 \%$ and averaged $19.0 \%$ (Table V). The PA was smallest in fourth order streams in spring and is probably due to the gritty nature of the growth. No trends for orders were found; however, period differences were significant. All periods were significantly different with the highest period mean being in the winter and lowest in summer.

\section{Partial Correlations}

The partial correlations, adjusted for effects and interactions of the design, reveal several significant linear relationships (Table VI). 
TABLE VI

PARTIAL CORRELATIONS OF VARIABLES ADJUSTED FOR ALL EFFECTS AND INTERACTIONS OF THE DESIGN

\begin{tabular}{|c|c|c|c|c|c|c|c|c|c|c|}
\hline & $\mathrm{CHL} \mathrm{A}_{-}$ & PHEO_A & DW & AFW & $\mathrm{PA}$ & $\overline{\mathrm{d}}$ & $\mathbf{J}$ & $\mathrm{d}$ & $S$ & $\mathrm{~S}_{\mathrm{d}}$ \\
\hline $\mathrm{CHL}$ A & - & $-0.56^{*}$ & 0.07 & 0.30 & 0.11 & 0.08 & 0.00 & 0.20 & 0.20 & 0.24 \\
\hline PHEO_A & & - & -0.16 & -0.47 & -0.18 & -0.32 & -0.32 & -0.03 & -0.03 & 0.04 \\
\hline DW & & & - & 0.17 & -0.22 & 0.07 & 0.05 & 0.06 & 0.06 & -0.09 \\
\hline AFW & & & & - & 0.50 & 0.13 & 0.18 & -0.03 & -0.03 & 0.00 \\
\hline PA & & & & & - & -0.01 & -0.05 & 0.16 & 0.17 & 0.18 \\
\hline$\overline{\mathrm{d}}$ & & & & & & - & $0.93^{*}$ & 0.18 & 0.18 & 0.13 \\
\hline $\mathrm{J}$ & & & & & & & - & -0.19 & -0.18 & -0.21 \\
\hline d & & & & & & & & - & $1.00^{*}$ & $0.96 *$ \\
\hline S & & & & & & & & & - & $0.96 *$ \\
\hline $\mathrm{S}_{\mathrm{d}}$ & & & & & & & & & & - \\
\hline
\end{tabular}

*Values significantly different from zero $(\alpha=0.05)$ 
Values of chlorophyll a were inversely related to pheophytin $\underline{\text { a. Variety }}$ and the number of species were almost perfectly correlated, reflecting the equivalence of the two parameters. Values of species diversity were highly correlated with equitability but not with variety or number of species. The number of diatoms were significantly correlated with both variety and total number of species, reflecting the preponderance of diatoms found in the study. No significant correlations existed between diversity indices and biomass or chlorophyll measurements. 


\section{CHAPTER VI}

\section{DISCUSSION}

The 85 taxa of periphyton, 78 of which were diatoms, collected in Otter Creek is comparable to the number found in other lotic studies in the state. In Byrd's Mill Spring, 133 total taxa, with 113 taxa of diatoms, were collected from glass slides and leaf detritus (Koch and Risser 1974). Koch (1975) found 68 taxa of diatoms in the Red River, of which 36 were halophilic. An environmental assessment of the Verdigris River revealed 116 species of periphyton, 78 of which were diatoms (Ecology Consultants, Inc. 1975). Another environmental assessment on the Arkansas River and two tributaries, near Ponca City, Oklahoma, revealed 80 total and 77 diatom taxa (Benham, Blair, and Affiliates, Inc. 1976). However, Cooper and Wilhm (1975) found only 22 taxa of algae, 15 of which were diatoms, in Skeleton Creek, a heavily polluted stream.

The number of total taxa in Otter Creek increased with order, while the number of taxa other than diatoms decreased. Data from the Metolius River, Oregon, showed that the number of taxa increased downstream below a spring and then leveled off (Sherman and Phinney 1971). However, the number of taxa other than diatoms followed the same pattern, which is the reverse of the trend for Otter Creek.

Diatom species may be replaced by more resistant forms of bluegreen, filamentous green, and flagellate algae in polluted areas (Fjerdingstad 1950, Blum 1957). The number of taxa is also usually 
reduced below an effluent and then increases downstream (Hynes 1960). The trends in taxa and types of taxa appear to be similar to what is found in mildly polluted streams. In earlier studies on the basin benthic macroinvertebrate and fish species tended to increase with order, these trends were attributed to physiographic succession (Harrel et al. 1967, Harrel and Dorris 1968).

The following species, in order of decreasing abundance, made up over $47 \%$ of the taxa identified: Nitzschia palea, Diploneis smithii, Gomphonema olivaceum, Navicula cryptocephala, Gomphonema parvulum, and Stigeoclonium tenue. Of the taxa listed above $\underline{G}$. parvulum, $\underline{N}$. crypto$\underline{\text { cephala }}$ N. palea, and $\underline{\mathrm{S}}$. tenue were listed as being among the top 20 most pollution-tolerant taxa of algae (Palmer 1969). In addition, Cyclotella meneghiniana, Melosira varians, Nitzschia acicularis, and Synedra ulna also in the top 20 , were present in the study. Species found in Otter Creek that seem to grow best when nitrate concentrations are high include Diatoma vulgare, N. palea, Surirella ovata and especially G. parvulum which is found particularly in waters containing sanitary or farm wastes (Patrick and Reimer 1966, 1975). Meridion circulare was the only pollution sensitive diatom that occurred in abundance.

Species diversity increased from the fourth to sixth order, but third order values were not significantly different from fourth order values. Fish species diversity tends to increase with stream order in natural streams (Whiteside and McNatt 1972, Lotrich 1973). Harrel and Dorris (1968) showed that the benthic macroinvertebrate diversity in Otter Creek increased from fourth to sixth order, but was slightly higher in the third than the fourth order. They noted that the 
diversity trend was similar to what might be found below a domestic effluent, but evidence showed it to be due to physiographic succession. Cooper and Wilhm (1975) found that $\overline{\mathrm{d}}$ was usually lowest directly below the source of effluent and improved downstream. In Red Rock and Greasy Creeks, two undisturbed tributaries of the Arkansas River, diversity tended to be higher in the upstream stations than in the downstream stations (Benham, Blair, and Affiliates, Inc. 1976).

Values of $\overline{\mathrm{d}}$ in Skeleton Creek and the two Arkansas River tributaries ranged from 0.3 to 2.2 and 1.57 to 3.82 , respectively (Cooper and Wilhm 1975, Benham, Blair, and Affiliates, Inc. 1976). The Arkansas River and Verdigris River values ranged from 0.11 to 2.97 and 1.17 to 3.03, respectively (Benham, Blair, and Affiliates, Inc. 1976, Ecology Consultants, Inc. 1975). The range in the present study, 2.45 to 3.64 , more closely compares to the values in the two small tributaries than in the large rivers. Staub et al. (1970) used phytoplankton species diversity to describe pollutional effects. They considered values from 0.00 to 1.00 to indicate heavy pollution, 1.00 to 2.00 to indicate moderate pollution, 2.00 to 3.00 to indicate light pollution, and values from 3.00 to 4.50 indicate slight pollution. Using this scheme the mean annual diversity values for the third and fourth orders might be considered lightly polluted, since values there were near 3.00 .

Equitability decreased from third to fourth order, but then increased through the sixth order. The four most abundant species always made up a higher percent composition in the fourth order than in any other order. Equitability values in the Verdigris River and the Arkansas River ranged from 0.27 to 0.71 and 0.03 to 0.70 , respectively (Ecology Consultants, Inc. 1975, Benham, Blair, and Affiliates, Inc. 
1976). In Greasy Creek and Red Rock Creek, values ranged from 0.34 to 0.79 and tended to be highest in the upstream stations (Behham, Blair, and Affiliates, Inc. 1976). As with species diversity the range of values for equitability is more comparable to the two creeks than to the rivers.

Variety increased with stream order and was almost perfectly correlated with the number of species. Harrel et al. (1967) found that variety of fish also increased with order in Otter Creek. In the East Gallatin River, Montana, which receives domestic effluent, variety decreased at first then increased downstream (Bahls 1973). Values varied from $2.90,5.3 \mathrm{~km}$ below the effluent, to $4.10,23.5 \mathrm{~km}$ below the effluent. Values in Otter Creek varied from 3.17 to 5.09. Sample sizes were similar in both studies.

The low correlation between species diversity and variety $(r=0.18)$ and the high correlation between species diversity and equitability $(r=0.93)$, apparently indicates that equitability has far more influence on species diversity than variety, as has been suggested by several authors (Sager and Hasler 1969, Brown 1973). Brown (1973) found the correlation between $\bar{d}$ and $J$ to be 0.97 , between $\bar{d}$ and $S$ to be 0.34 , and between $J$ and $S$ to be 0.09 . These values are comparable to those found in the present study (Table V).

The range of values for ash-free weight $/ \mathrm{m}^{2}, 0.31$ to $3.51 \mathrm{~g} / \mathrm{m}^{2}$, was comparable to the range found in the two tributaries of the Arkansas River, 0.06 to $4.62 \mathrm{~g} / \mathrm{m}^{2}$ (Benham, Blair, and Affiliates, Inc. 1976). In Skeleton Creek values were highest below an efflyent and tended to decrease downstream (Cooper and Wilhm 1975). The trend of decreasing values with increased stream order in Otter Creek is similar to the 
trend in a polluted stream. Values in the Verdigris and Arkansas Rivers ranged from 0.15 to $20.88 \mathrm{~g} / \mathrm{m}^{2}$ and 0.06 to $5.02 \mathrm{~g} / \mathrm{m}^{2}$, respectively (Ecology Consultants, Inc. 1975, Benham, Blair, and Affiliates, Inc. 1976). Values in Skeleton Creek, a heavily polluted stream, ranged from 5.0 to $29.0 \mathrm{~g} / \mathrm{m}^{2}$ of ash-free weight (Cooper, personal communication). Biomass in the Columbia River varied from 0.24 to $4.00 \mathrm{~g} / \mathrm{m}^{2}$ (Cushing 1967) and from 1.0 to $3.8 \mathrm{~g} / \mathrm{m}^{2}$ in the Red Cedar River, Michigan (King and Ball 1966).

Annual stream order means of chlorophyll a decreased with increased stream order values ranged from 0.21 to $15.34 \mathrm{mg} / \mathrm{m}^{2}$. In Red Rock Creek values were highest upstream, while in Greasy Creek values were highest downstream (Benham, Blair, and Affiliates, Inc. 1976). Values ranged from 0.2 to $30.8 \mathrm{mg} / \mathrm{m}^{2}$ in both streams. These values are somewhat comparable to those in Otter Creek. In the Duwamish Green River, Washington, values were smallest in the upper reaches $\left(8.0 \mathrm{mg} / \mathrm{m}^{2}\right)$ and consistently increased downstream to $43.0 \mathrm{mg} / \mathrm{m}^{2}$ (Tilley and Haushild 1975). This increase was attributed to nutrient accumulation down the stream's course and should be expected in other streams. As with ashfree weight, the trend and not the magnitude suggests light pollution. Also, in the third order pheophytin a was always highest which may indicate that the assemblage present is in poor physiological condition. The diversity indices performed as might be expected for either a recovery zone below an effluent or physiographic succession. Species composition, number of taxa, biomass, and chlorophyll a values suggest mild nutrient enrichment. The upper reaches of Otter Creek contains considerable pastureland and several small cattle feedlots. It is possible that runoff from these may have caused the perturbation. 
Physiographic succession was masked by this disturbance and could not be delineated with stream order. However, stream order did separate the stream into convenient segments that had similar characteristics within them. 


\section{CHAPTER VII}

\section{SUMMARY}

1. Periphyton was collected from third, fourth, fifth, and sixth order streams in Otter Creek, Oklahoma, during winter, spring, and summer, 1975. Species composition, diversity, ash-free weight, and chlorophyll a were analyzed for differences among stream orders.

2. A total of 85 taxa of periphyton were collected. The number of taxa, number of diatom taxa, and species composition was similar to other studies in the state. The number of taxa other than diatoms was always highest in the third order and tended to increase with order. A large number of pollution-tolerant algae were also present in the study. The trends for species composition, number of taxa, and type of taxa suggested some form of mild nutrient enrichment.

3. Species diversity, equitability, and variety were lowest in the third and fourth order and then increased with order. The values of species diversity in the third and fourth orders were considered marginal for light pollution.

4. Chlorophyl1 a and ash-free weight values decreased with increased order. These trends also reflected probable nutrient enrichment.

5. The effects of pollution masked physiographic succession. However, stream order did separate the stream into convenient segments that had similar characteristics within them. 


\section{LITERATURE CITED}

Bahls, L. L. 1973. Diatom community response to primary wastewater effluent. J. Water Pollut. Contr. Fed. 45:134-144.

Ball, R. C., N. R. Kevern, and T. A. Haines. 1973. An ecological evaluation of stream eutrophication. Tech. Rep. No. 36. Inst. Water Res. Michigan State University, East Lansing.

Benham, Blair, and Affiliates, Inc. 1976. Sooner Site, final report. Benham, Blair, and Affiliates, Inc., 6323 N. Grand Boulevard, Okl ahoma City, OK.

Blum, J. L. 1954. Two winter diatom communities of Michigan streams. Pap. Mich. Acad. Sci., Arts and Lett. 39:3-7.

Blum, J. L. 1956. The ecology of river algae. Bot. Rev. 22:291-340.

Blum, J. L. 1957. An ecological study of the Saline River, Michigan. Hydrobiologia 9:361-408.

Brown, S. D. 1973. Species diversity of periphyton communities in the littoral of a temperate lake. Int. Rev. ges. Hydrobiol. 58:787-800.

Budde, H. 1932. Limnologische Untersuchungen niederrheinischer und westfalischer Gewasser. Die Algenflora der Lippe und ihrer Zuflüsse. Arch. Hydrobiol. 24:187-252.

Butcher, R. W. 1932a. An apparatus for studying the growth of epiphytic algae with special reference to the River Tees. Trans. N. Natur. Union 1:1-15.

Butcher, R. W. 1932b. Studies in the ecology of rivers. II. The microflora of rivers with special reference to the algae on the river-bed. Ann. Bot. 46:813-861.

Butcher, R. W. 1940. Studies in the ecology of rivers. IV. Observations on the growth and distribution of the sessile algae in the River Hull, Yorkshire. J. Ecol. 28:210-223.

Butcher, R. W. 1946. Studies in the ecology of rivers. VI. Algal growth in certain highly calcareous streams. J. Ecol. 33:268-283.

Butcher, R. W. 1947. Studies in the ecology of rivers. VII. The algae of organically enriched water. J. Ecol. 35:186-191. 
Castenholz, R. W. 1961. An evaluation of a submerged glass method of estimating production of attached algae. Verh. Int. Verein. Limnol. 14:155-159.

Cooke, G. D. 1967. The pattern of autotrophic succession in laboratory microcosms. Bioscience 17:717-721.

Cooke, W. B. 1956. Colonization of artificial bare areas by microorganisms. Bot. Rev. 22:613-638.

Cooper, J. M., and J. L. Wilhm. 1975. Spatial and temporal variation in productivity, species diversity, and pigment diversity of periphyton in a stream receiving domestic and oil refinery effluents. Southwest. Natur. 19:413-428.

Cushing, C. 1967. Periphyton productivity and radionuclide accumulation in the Columbia River, Washington, U. S. A. Hydrobiologia $16: 125-139$.

Dillard, G. E. 1969. The benthic algal communities of a North Carolina piedmont stream. Nova Hedwigia XVII (Supp.):9-29.

Dillard, G. E. 1971. An epilithic diatom community of a North Carolina sandhills stream. Rev. Algol. 2:118-127.

Douglas, B. 1958. The ecology of the attached diatoms and other algae in a small stony stream. J. Ecol. 46:295-322.

Ecology Consultants, Inc. 1975. Black Fox Station, final report. Ecology Consultants, Inc., P. 0. Box 1057, Fort Collins, C0.

Eddy, S. 1925. Freshwater algal succession. Trans. Amer. Microsc. Soc. $44: 138-147$.

Fitzpatrick, E. G., W. C. Boatright, and L. E. Rose. 1939. Soil survey of Garfield County, Oklahoma. U. S. Dept. Ag., Bureau of Chem. of Soils. 48 p.

Fjerdingstad, E. 1950. The microflora of the River Molleaa with special reference to the relation of benthal algae to pollution. Folia Limnol. Scand. 5:1-124.

Forbes, S. A. 1913. Biological and chemical conditions on the upper Illinois River. Proc. 5th Ill. Water Supply Ass. 161-170.

Forbes, S. A., and R. E. Richardson. 1913. Studies on the biology of the upper Illinois River. Bull. Ill. Natur. Hist. Surv. 9:481-574.

Fraleigh, P. C., and R. G. Wiegert. 1975. A model explaining successional change in standing crop of thermal blue-green algae. Ecology 56:656-664.

Frank, P. W. 1968. Life histories and community stability. Ecology $49: 355-357$. 
Galloway, H. M. 1960. Soil survey of Logan County, Oklahoma. U. S. Dept. Ag., Soil Conserv. Serv. 60 p.

Gravelius, H. 1914. Flusskunde, Goschen'sche Verlagshandlung. Berlin. $176 \mathrm{p}$.

Gray, F., and H. M. Galloway. 1959. Soil of Oklahoma. Okla. State Univ., Agr. Exp. Sta., Misc. Publ. MP-56. 65 p.

Grzenda, A. R., and M. L. Brehmer. 1960. A quantitative method for the collection and measurement of stream periphyton. Limnol. Oceanog. $5: 190-194$.

Gumtow, R. B. 1955. An investigation of the periphyton in a riffle of the West Gallatin River, Montana. Trans. Amer. Microsc. Soc. $74: 278-292$.

Harrel, R. C. 1966. Stream order and community structure of benthic macroinvertebrates and fishes in an intermittent stream. Ph.D. Thesis, Okla. State Univ. $76 \mathrm{p}$.

Harrel, R. C., B. J. Davis, and T. C. Dorris. 1967. Stream order and species diversity of fishes in an intermittent Oklahoma stream. Amer. Midl. Natur. 78:428-436.

Harrel, R. C., and T. C. Dorris. 1968. Stream order, morphometry, physico-chemical conditions, and community structure of benthic macroinvertebrates in an intermittent stream system. Amer. Midl. Natur. 80:220-251.

Hohn, M. H., and J. Hellerman. 1963. The taxonomy and structure of diatom populations from three eastern North American rivers using three sampling methods. Trans. Amer. Microsc. Soc. 82:250-329.

Horton, R. E. 1945. Erosional development of streams and their drainage basins. Geol. Amer. Bull. 56:275-370.

Hustedt, F. 1930. Bacillariophyta, in: A. Pascher (ed.), Die Susswasser-Flora Mitteleuropas, Heft 10. Gustav Fischer, Jena.

Hutchinson, G. E. 1975. A treatise on Limnology. Vol. III. Limnological Botany. John Wiley and Sons, New York. $660 \mathrm{p}$.

Hynes, H. B. N. 1960. The biology of polluted waters. Liverpool Univ. Press, Liverpool. 202 p.

Hynes, H. B. N. 1970. The ecology of running waters. Univ. Toronto Press, Toronto. $555 \mathrm{p}$.

Ivlev, V. W. 1933. Ein Versuch zur experimentellen Erforschungder Okologie der Wasserbiöconosen. Arch. Hydrobiol. 25:177-191. 
Johnson, R., R. Richards, and D. W. Blinn. 1975. Investigation of diatom populations in rhithron and potamon communities in Oak Creek, Arizona. Southwest. Natur. 20:197-204.

Karsinkin, G. 1934. Zur. Studium des bakterialen Periphytons. Arb. Limnol. Stat. Kossino 17:21-44. (not seen, ref. Hutchinson 1975)

Kawecka, B. 1974. Vertical distribution of algae communities in Maljovica stream (Rila-Bulgaria). Pol. Arch. Hydrobiol. 21:211-228.

Kehde, P. M., and J. L. Wilhm. 1972. The effects of graxing by snails on community structure of periphyton in laboratory streams. Amer. Midl. Natur. $87: 8-24$.

Kevern, N. R., J. L. Wilhm, and G. M. Van Dyne. 1966. Use of artificial substrate to estimate the productivity of periphyton. Limnol. Oceanog. $11: 74-87$.

King, D., and R. Ball. 1966. A qualitative and quantitative measure of aufwuchs production. Trans. Amer. Microsc. Soc. 85:232-240.

Koch, A. 1975. Diatoms, including salt-water taxa, from southwestern Okl ahoma. Proc. Okla. Acad. Sci. 55:11-13.

Koch, A., and P. Risser. 1974. Species composition and relative biomass of algal communities on leaf detritus in a spring-fed stream. Proc. Okla. Acad. Sci. 54:14-19.

Kuehne, R. A. 1962. A classification of streams illustrated by distribution in an eastern Kentucky creek. Ecology 43:608-614.

Lorenzen, C. J. 1967. Determination of chlorophyll and pheopigments: spectrophotometric equations. Limnol. Oceanog. 12:343-346.

Lotrich, V. A. 1973. Growth, production, and community composition of fishes inhabiting a 1st, 2nd, and 3rd order stream of eastern Kentucky. Ecol. Mon. 43:377-397.

Lund, J. W. G., and J. F. Talling. 1957. Botanical limnological methods with special reference to the algae. Bot. Rev. 23:489-583.

Margalef, R. 1951. Diversidad de especies en les communidades maturales. P. Inst. Biol. Ap1. 9:5-27.

Margalef, R. 1958. Temporal succession and spatial heterogeneity in phytoplankton. Pages 323-347 in Perspectives in Marine Biology. Univ. Calif. Press, Berkeley.

Margalef, R. 1960. Ideas for a synthetic approach to the ecology of running waters. Int. Rev. ges. Hydrobiol. 45:133-155.

Margalef, R. 1968. Perspectives in ecological theory. Univ. Chicago Press, Chicago. $111 \mathrm{p}$. 
McConnell, W. J., and W. F. Sigler. 1959. Chlorophyll and productivity in a mountain river. Limnol. Oceanog. 4:335-351.

McIntire, C. D. 1966. Some effects of current velocity on periphyton communities in laboratory streams. Hydrobiologia 27:559-570.

Naumann, E. 1915. Skrifter utg. av S. Sveriges Fiskeriforening. Lund, 1915. (not seen, ref. Cooke 1956)

Newcombe, C. L. 1949. Attachment materials in relation to water productivity. Trans. Amer. Microsc. Soc. 58:355-361.

Newcombe, C. L. 1950. A quantitative study of attachment materials in Sodon Lake, Michigan. Ecology 31:204-215.

Odum, E. P. 1969. The strategy of ecosystem development. Science $164: 262-270$.

Odum, E. P. 1971. Fundamentals of Ecology. W. B. Saunders Co., Philadelphia. $574 \mathrm{p}$.

Odum, H. T. 1956. Primary production of flowing waters. Limnol. Oceanog. 1:102-117.

Odum, H. T., and R. C. Pinkerson. 1955. Times speed regulator, the optimum efficiency for maximum output in physical and biological systems. Amer. Sci. 43:331-343.

Palmer, G. 1969. A composite rating of algae tolerating organic pollution. J. Phycol. 5:78-82.

Patrick, R. 1967. The effect of invasion rate, species pool, and size of area on the structure of the diatom community. Proc. Nat. Acad. Sci. 58:1335-1342.

Patrick, R. 1968. The structure of diatom communities in similar conditions. Amer. Natur. 102:173-183.

Patrick, R., M. H. Hohn, and J. H. Wallace. 1954. A new method for determining the pattern of the diatom flora. Notul. Natur. 259: $1-12$.

Patrick, R., and C. Reimer. 1966. The diatoms of the United States, Vol. I. Philadelphia Acad. Natur. Sci., Mon. No. 13. Philadelphia.

Patrick, R., and C. Reimer. 1975. The diatoms of the United States, Vol. II, pt. I. Philadelphia Acad. Natur. Sci., Mon. No. 13. Philadelphia.

Patten, B. C. 1962. Species diversity in net phytoplankton of Raritan Bay. J. Mar. Res. 20:57-75.

Pielou, E. C. 1966. The measurement of diversity in different types of bialogical collections. J. Theoret. Biol. 13:131-144. 
Prescott, G. 1962. Algae of the western Great Lakes area. W. C. Brown Co., Dubuque, Iowa.

Reisen, W. K., and D. J. Spencer. 1970. Succession and current demand relationships of diatoms on artificial substrates in Prater's Creek, South Carolina. J. Phycol. 6:117-121.

Ryther, J. H. 1956. Photosynthesis in the ocean as a function of light intensity. Limnol. Oceanog. 1:61-70.

Sager, P., and A. Hasler. 1969. Species diversity in lacustrine phytoplankton. I The components of the index of diversity from Shannon's formula. Amer. Natur. 103:51-59.

Sheldon, A. L. 1969. Equitability indices: Dependence on the species count. Ecology 50:466-467.

Sherman, B. J., and H. K. Phinney. 1971. Benthic algal communities of the Metolius River. J. Phycol. 7:269-273.

Sladecek, V., and A. Sladeckova. 1964. Determination of the periphyton production by means of the glass slide method. Hydrobiologia $23: 125-158$.

Sladeckova, A. 1962. Limnological investigation methods for the periphyton ("Aufwuch") community. Bot. Rev. 28:287-350.

Staub, R., J. W. Appling, A. M. Hof stetter, and I. J. Haas. 1970. The effect of industrial waste of Memphis and Shel by County on primary plankton producers. Bioscience 20:905-912.

Steel, R., and J. Torrie. 1960. Principles and procedures of Statistics. McGraw-Hill Book Co., Inc., New York.

Strahler, A. N. 1954. Quantitative geomorphology of erosional 1 andscapes. C. R. 19th Int. Geol. Cong., Sec. 13:341-354.

Strahler, A. N. 1957. Quantitative analysis of watershed geomorphology. Trans. Amer. Geophys. Union 38:913-920.

Symoens, J. J. 1951. Esquisse d!un systeme des associations algales d'eau douce. Verh. Int. Ver. Theor. Ang. Limnol. 11:395-408.

Tilley, L。 J., and W. L. Haushild. 1975a. Net primary productivity of

periphyton in the intertidal zone, Duwamish River estuary, Washington. J. Res. U. S. Geol. Surv. 3:253-259.

Tilley, L. J., and W. L. Haushild. 1975b. Use of productivity of periphyton to estimate water quality. J. Water Pollut. Contr. Fed. 42:2157-2171.

U. S. Geological Survey. 1945. Oklahoma water. Washington, D. C. 145 p. 
Waters, T. R. 1961. Notes on the chlorophyll method of estimating the photosynthetic capacity of stream periphyton. Limnol. Oceanog. $6: 486-488$.

Weber, C. I., ed. 1973. Biological field and laboratory methods for. measuring the quality of surface waters and effluents. EPA-670/4-73-001. Cincinnati, Ohio.

Whitaker, R. H. 1965. Dominance and diversity in land plant communities. Science 147:250-260.

Whiteside, B. G., and R. M. McNatt. 1972. Fish species diversity in relation to stream order and physicochemical conditions in the Plum Creek drainage basin. Amer. Midl. Natur. 88:90-101.

Wiegert, R. G., and P. C. Fraleigh. 1972. Ecology of Yellowstone thermal effluent systems: Net primary production and species diversity of a successional blue-green algal mat. Limnol. Oceanog. $17: 215-228$.

Wilhm, J. L. 1970. Range of diversity index in benthic macroinvertebrate populations. J. Water Pollut. Contr. Fed. 42:R221-R224.

Wilhm, J. L. 1976. Species diversity of fish populations in Oklahoma reservoirs. Ann. Okla. Acad. Sci. 6:29-46.

Wilhm, J. L., and T. C. Dorris. 1968. Biological parameters for water quality criteria. Bioscience 18:477-481.

Wilhm, J. L., and J. Long. 1969. Succession in algal mat communities at three different nutrient levels. Ecology 50:645-652.

Williams, L., and C. Scott. 1962. Prinicpal diatoms of major waterways of the United States. Limnol. Oceanog. $7: 365-379$.

Yentsch, C. S., and D. W. Menzel. 1963. A method for the determination of phytoplankton chlorophyll and pheophytin by florescence. Deep Sea Res. 10:221-231.

Young, O. A. 1945. A limnological investigation of periphyton in Douglas Lake, Michigan. Trans. Amer. Microsc. Soc. 64:1-20.

Yount, J. L。 1956. Factors that control species numbers in Silver Springs, Florida. Limnol. Oceanog. 1:286-295. 


\author{
VITA \\ James Randal1 Seyfer \\ Candidate for the Degree of \\ Master of Science
}

Thesis: VARIATION WITH STREAM ORDER IN SPECIES COMPOSITION, DIVERSITY, BIOMASS, AND CHLOROPHYLL OF PERIPHYTON IN OTTER CREEK, OKLAHOMA

\title{
Major Field: Zoology
}

Biographical :

Personal Data: Born in Nebraska City, Nebraska, October 3, 1951, the son of Randall W. and Mary E. Seyfer.

Education: Graduated from Nebraska City Public High School, Nebraska City, Nebraska, in May, 1970; received a Bachelor of Science degree in Biology from Kearney State College, Kearney, Nebraska, in May, 1974; completed requi rements for a Master of Science degree in Zoology at Oklahoma State University in July, 1976.

Professional Experience: Technician, Nebraska Dept. of Environ. Control, September, 1973, and May, 1974; Vascular Plant Taxonomist, Kearney State College, Kearney, Nebraska, May, 1974, to August, 1974; Literature Researcher, Kearney State College, Kearney, Nebraska, May, 1974, to August, 1974; Aquatic Ecologist, Aquatic Life Consultants, Inc., Stillwater, Okl ahoma, August, 1974, to December, 1974; Aquatic Ecologist, Technology Research and Development, Inc., Okl ahoma City, Okl ahoma, February, 1975, to January, 1976; Graduate Research Assistant for Reservoir Research Center, Okl ahoma State University, Stillwater, Oklahoma, September, 1975, to July, 1976.

Professional Affiliations: American Society of Limnology and Oceanography, Beta Beta Beta, North American Benthological Society, and the Oklahoma Academy of Science. 